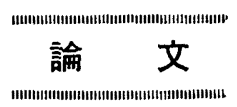

UDC $669.12: 539.55: 548.735: 620.186 .6: 620.186 .8$

\title{
純鉄の勒性におよぽす集合組織の影響*
}

\author{
寺 崎 富久長**. 金 子 輝 雄***
}

\section{Effect of Texture on the Toughness of Pure Iron}

Fukunaga TERASAKI and Teruo Kaneko

Synopsis:

To clarify the effect of texture on the toughness of irons and steels, mechanical behaviors of pure irons having a strong $\{100\}\langle 011\rangle$ texture component were investigated.

It is revealed that the texture has a notable influence on the Charpy impact properties; the stronger the $\{100\}$ component parallel to the fracture surface, the higher the impact transition temperature. The ratio of unit crack path $l_{\mathrm{C}}$ to grain size $l_{\alpha}$ in the textured sample is larger than the ratio of about 2 obtained in a previous paper ${ }^{18)}$. It can be concluded that the unit crack path is more reasonable than the grain size as a characteristic of the structure affecting on the toughness of irons. The difference of the fractographic appearance of unit crack path between the textured sample and the random one is discussed.

The elongation and the reduction in width show the planar anisotropy due to the preferred orientations, while the strength is not influenced by the texture under the experimental conditions of this study.

(Received Feb. 23, 1974)

\section{1. 緒言}

集合組織は鋼の機械的性質や磁気的性質に種々の影響 を与えることが知られており，とくに冷延鋼板において は深絞り性 (Lankford 值), 面内異方性, 伸びなどの諸 性質と集合組織との関係について多くの報告がなされて いる1) 4)，一方厚鋼板については最近まで集合組織的観 点からの調査はほとえどなされていないが，厚鋼板にお いても成分や压延条件によつては強い集合組織が形成さ れる場合がある(5) ，厚鋼板の性質としては強度, 靶性, 延性が重要なものであるが, 単結晶のデータからみてこ れらの性質は結晶方位依存性を有しておりて〜9，したが つて集合組織の影響は大きいと考えられる10) 11). また 衝慗試呀などの破面に 'separation'あるいは'delamination’ と称される制離割れが生じる場合があり，con一 trolled rolling のように低温域で圧延を行なうと特にこ の 'separation’が顕著にみられる. ‘separation' の成因 については種々議論があるが，狳離部が䢃開破壊である という報告もあり12) 13)，乙の点からも靭性と集合組織 の関係を明らかにしておく必要がある。

鋼の䩒性に影響を与元る因子としては，合金元素，介
在物や析出物などの第二相粒子, 残留歪, 組織などが挙 げられる，従来組織の影響としては結晶粒度依存性がよ く知られているが14～16)，これに対して筆者の一人らは 組織の影響を破面単位で整理することによつて，より統

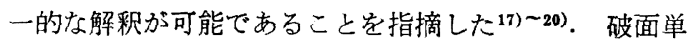
位は微細重裂の生成伝播が生じている領域に相当し，そ の領域內では破壊の生じている結晶面の方位がほぼ同一 の $\{100\}$ 面をなしている.

ところで一般に鋼をフェライト域で圧延した場合の圧 延集合組織では, 压延面に平行な $\{100\}$ 方位が主方位の 一つであるが，これは脆性破壊の䢃開面と一致してい る.したがつて強い压延集合組織を有する材料では, 鞠 性に対してこの\{100\} 策合組織が影響を与えると考えら れ，また破面巣位の役割もより明らかになることが期待 される.

以上の観点に従い，本報では成分，第二相粒子などの 影響をできるだけ少なくするため純鉄を用い，圧延面に

* 昭和 48 年 4 月 本会講演大会にて発表 昭和49年 2 月 23 日 受付

** 住友金属工業(株)中央技術研究所工博

****住友金属工業(株)中央技術研究所 
Table 1. Chemical composition and processing detail of materials used.

\begin{tabular}{|c|c|c|c|c|c|c|c|}
\hline Sample & C & $\mathrm{Si}$ & $\mathrm{Mn}$ & $\mathrm{P}$ & $\mathrm{S}$ & $\mathbf{N}$ & $\mathrm{O}$ \\
\hline A & 0.014 & 0.017 & $<0.01$ & 0.003 & 0.007 & $0 \cdot 0016$ & 0.005 \\
\hline B & 0.008 & 0.010 & $<0.01$ & 0.003 & 0.006 & 0.0012 & 0.005 \\
\hline C & 0.013 & 0.032 & $<0.01$ & 0.003 & $0 \cdot 005$ & 0.0016 & 0.005 \\
\hline
\end{tabular}

(wt. \%)

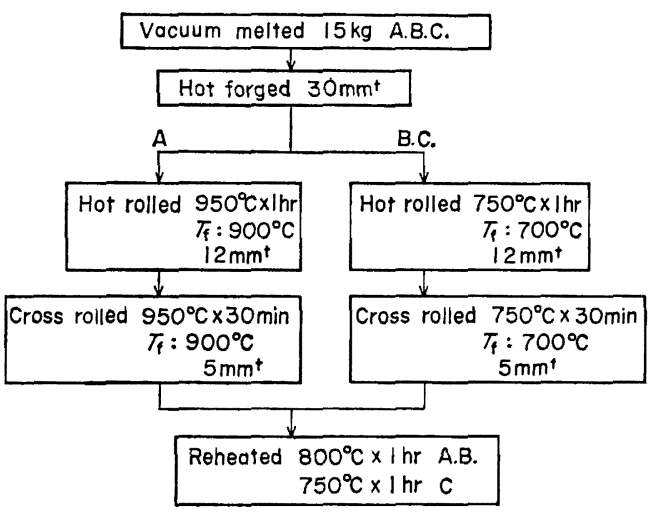

$T_{\mathrm{f}}$ : finishing temperature

平行な強い $\{100\}$ 組織を有する材料と集合組織のランダ ムな材料について䩲性と集合組織の関係を調査した結果 を報告する。

\section{2. 供試材と実験方法}

\section{1 供試材の製作}

供試材の化学成分と製作条件を Table 1 亿示す. 供試 材はいずれも電解鉄を真空溶解により溶製したものであ る. 銅塊（各 $15 \mathrm{~kg}$ ） $1250^{\circ} \mathrm{C}$ に加熱し $900^{\circ} \mathrm{C}$ 以上 で $30 \mathrm{~mm}$ 厚まで熱間鍛造した。

次化試料 $\mathrm{B}$ と $\mathrm{C}$ は, $750^{\circ} \mathrm{C} \times 1 \mathrm{hr}$ 加熱後 $700^{\circ} \mathrm{C}$ 以上 で一次圧延を行ない $12 \mathrm{~mm}$ 厚とした. さらに $750^{\circ} \mathrm{C} \times$ $30 \mathrm{~min}$ 再加熱後一次圧延之直角の方向に二次圧延を行な い700 $\mathrm{C}$ 以上で $5 \mathrm{~mm}$ 厚に仕上げた.ここで約 $700^{\circ} \mathrm{C}$ の低温で交又圧延を行なつたのは圧延面に平行な強いし かも分散の小さい $\{100\}$ 組織を得るためである. また交 刃圧延を行なつているので $\mathrm{MnS}$ などの介在物形状によ る面内異方性の影響が少なくなるという効果もある.

試料 $\mathrm{A}$ は集合組織のランダムな材料を得るため, 加熱 温度を $950^{\circ} \mathrm{C}$ とし $900^{\circ} \mathrm{C}$ 以上で圧延した. 圧延は試料 $\mathrm{B}, \mathrm{C}$ と同様の手順で交叉圧延を行なつた.

圧延後は歪を除去するため, 試料 $\mathrm{A}, \mathrm{B}$ は $800^{\circ} \mathrm{C} \times 1 \mathrm{hr}$, 試料 $\mathrm{C}$ 泣 $750^{\circ} \mathrm{C} \times 1 \mathrm{hr}$ の焼鉵を加えた、X線回折線の幅 拡がりから昰量を測定した結果, 各試料とも完全に焼鈍
Table 2. Grain size observed in various sections of samples (unit : $\mu$, measured by linear analysis)

\begin{tabular}{l|c|r|c}
\hline & A & B & C \\
\hline (a) $Z$ & $40 \cdot 1$ & $102 \cdot 6$ & $71 \cdot 6$ \\
(b) $0^{\circ}$ & $38 \cdot 5$ & $80 \cdot 5$ & $58 \cdot 4$ \\
(c) $45^{\circ}$ & $39 \cdot 1$ & $82 \cdot 8$ & $58 \cdot 5$ \\
\hline
\end{tabular}

(a) : normal section parallel to rolling plane

(b) : cross section perpendicular to rolling direction (R. D.)

(c) : cross section of $45^{\circ}$ to R. D.

した材料と同程度の幅広がりを示しており，压延歪はほ ほ除去されていると考えられる。

\section{2 供試材の結晶粒度}

压延面に平行な面および圧延方向（以後圧延方向とは 二次圧延の方向をさす。）から $0^{\circ}, 45^{\circ}$ の断面について 光学顕微鏡観察を行ない，線分析により結晶粒度を測定 した．測定結果を Table 2 に，また観察の一例を Photo. 1 に示与。な抔食液としてはFry 試薬を用いた。試料 $\mathrm{A}$ 注等軸粒，試料 $\mathrm{B} ， \mathrm{C}$ はややパンケーキ型に近い粒形 を示している.

\section{3 供試材の集合組彎}

压延面に平行な面および圧延方向から $0^{\circ} ， 45^{\circ}$ の断面 について 200 極点図を求的た．測定は主として反射法で 行ない，圧延面に平行な面については透過法も用い全極 点図を求めた。

Fig. 1 は試料 Bの 200 極点図を示したものである. 圧 延面に平行な面についての極点図 (a) より，この試料で は\{100\}〈011〉に㥛めて強い集積を有することがわかる.

これは圧延方向から $0^{\circ}$ と $45^{\circ}$ の断面についての極点図 (b)，（c）からも確めることができる. 試料 $\mathrm{C}$ について はここに示さないが, 試料 $\mathrm{B}$ と同様圧延面に平行な強い $\{100\}\langle 011\rangle$ 組織を有し集積度も同程度であつた.

これに対して試料Aでは, Fig. 2 に示すようにいずれ の面についても強い集積は認められず, 集合組織はほほ ランダムである.

このように压延面に平行な強い $\{100\}$ 組織を有する試 料 $\mathrm{B} ， \mathrm{C}$ と集合組織のランダムな試料 $\mathrm{A}$ とが得られた.

これらの試料を用いて以下の試験を行なつた。

\section{4 引張試験}

強度と延性におよぼす集合組織の影響を調べるため, 圧延方向から $10^{\circ}$ おきに $90^{\circ}$ までの各方向に試験片を 切り出し引張試験を行なつた. 試験片の寸法を Fig. 3 に 示す. 試験はインストロン引張試験機により室温で行な つた. 引張速度は $5 \mathrm{~mm} / \mathrm{min}$ を用いた。

\section{5 シャルピー衝繋試験}

靬性に㧍よぼす集合組織の影響を調べるため，正延方 


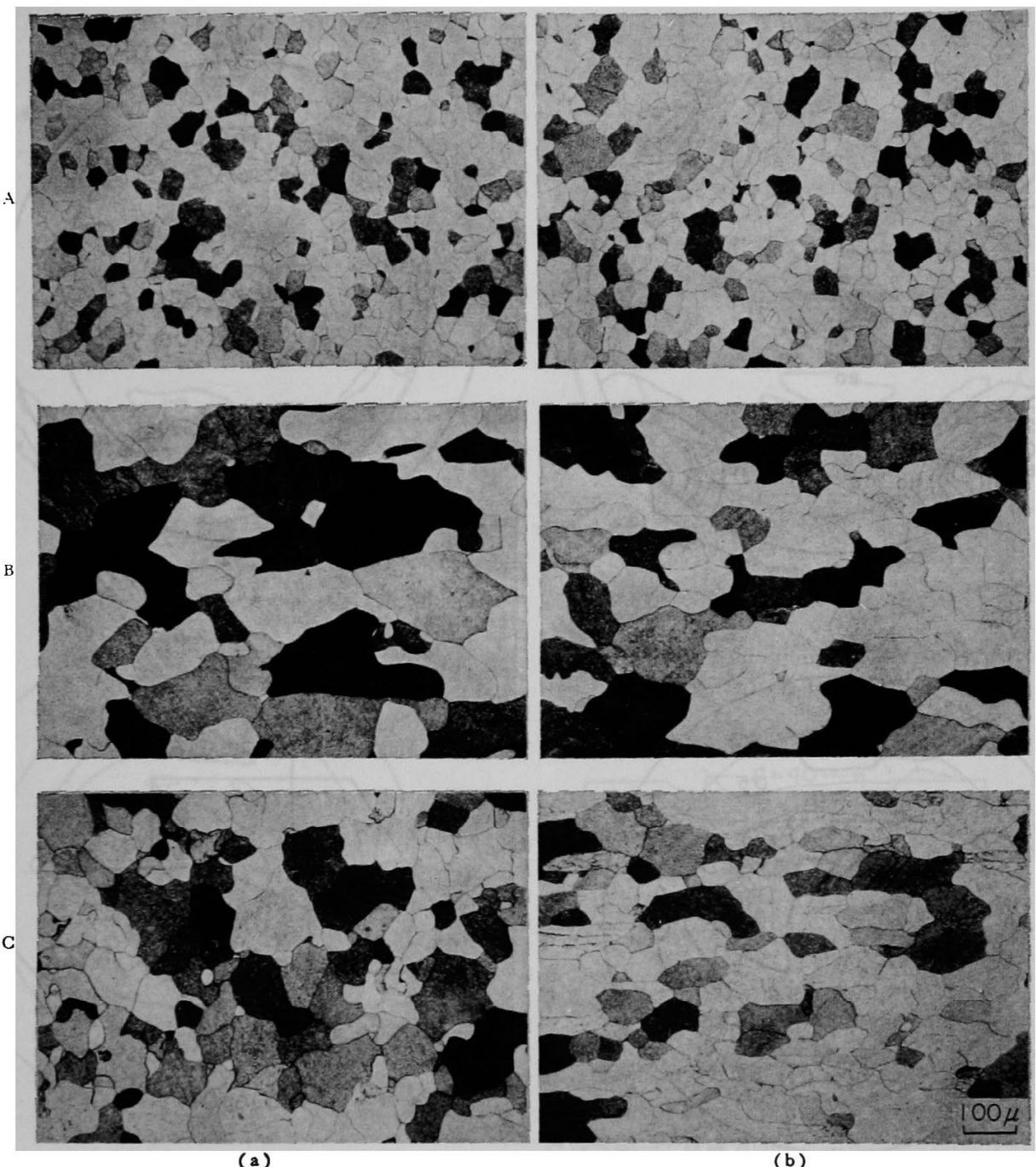

Photo. 1. Optical microstructures of materials used : (a) normal section parallel to rolling plane (b) cross section perpendicular to rolling direction.

向から $0^{\circ}, 22 \cdot 5^{\circ}, 45^{\circ}, 90^{\circ}$ (たたし $90^{\circ}$ 方向は試料 Cのみ) および板厚方向についてシャルピー衝撃試験を 行なつた.

Fig. 4 に試験片の寸法を示しておくが,いうれも $2 \mathrm{~mm}$ V 切欠を有する $5 \mathrm{t} \times 10 \mathrm{w} \times 551(\mathrm{~mm})$ のサブサイズ試験 片である．板厚方向については，供試材は $5 \mathrm{~mm}$ 厚であ るので両側に同一材料の継手を電子ピーム溶接すること により $55 \mathrm{~mm}$ 長さとした.

\section{6 破面の轠察}

衝撃試験後の破面について, 走査型電子顕微鏡による 二次電子線像を用いて観察を行ない，破面単位を測定し た.

\section{3. 実 験 結 果}

\section{1 強度におよぼす集合組織の影響}

Fig. 5 は降伏応力と引張強度の結果を示したものであ る. 降伏応力, 引張強度に関してはいずれの試料とも圧 延面内での異方性は認められない。

単結晶のデータでは, 降伏応力の結晶方位による差は ほとんどないが,引張強度では差があるとされている21). また多結晶でも低温で引張つた場合には，降伏応力，破 壊応力に対して集合組織の影響があるという報告もなさ れている22)，本実験の範囲では，強い $\{100\}\langle 011\rangle$ 集合 組織を有する試料でも強度の面内異方性はなく，集合組 


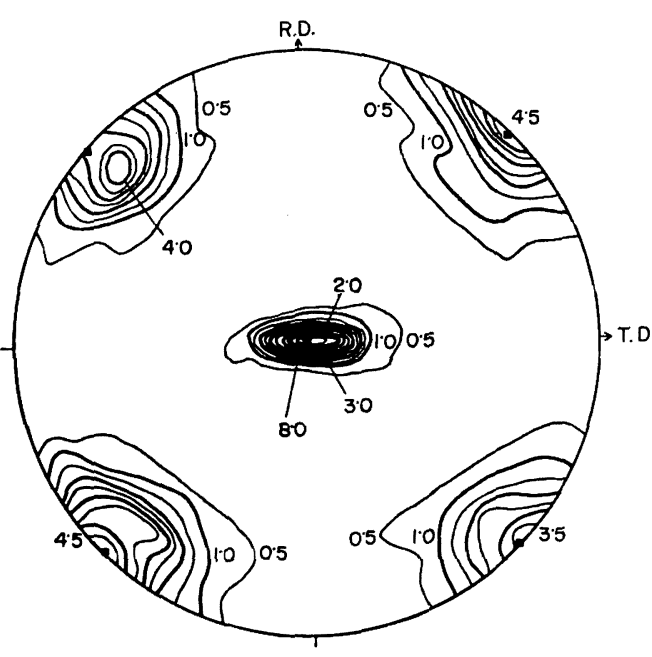

(a)

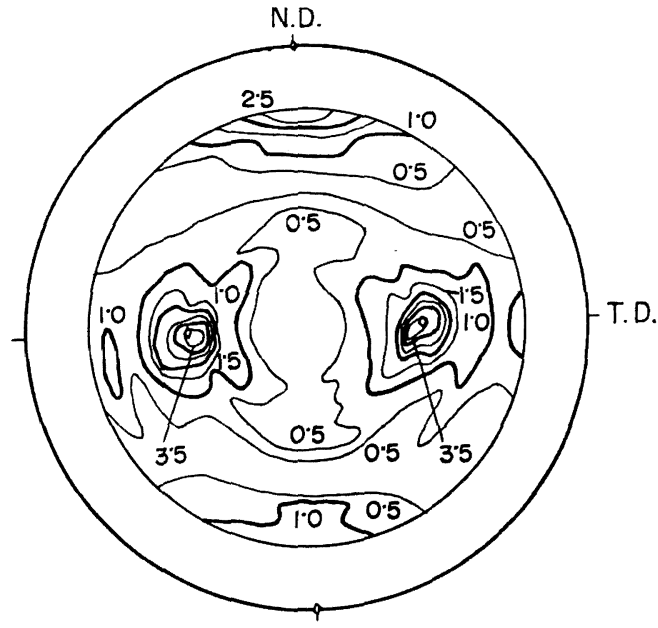

(b)

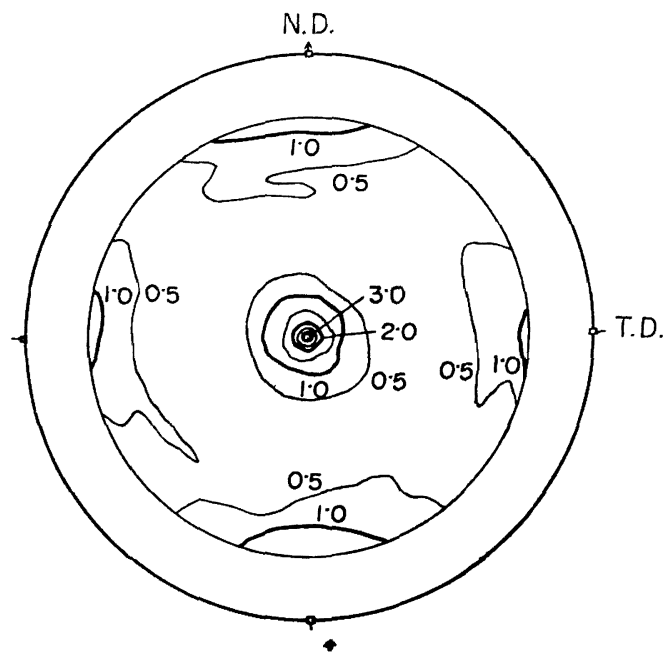

(c)

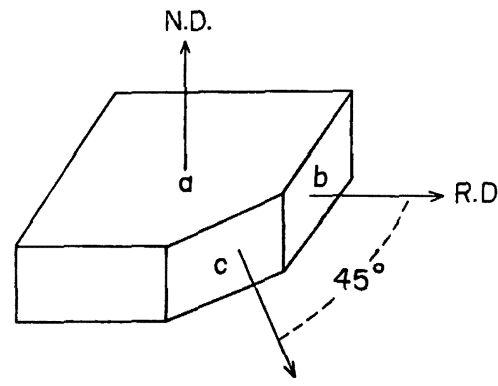

- $0:\{100\}<011>$

Fig. 1. 200 pole figures of sample $B$, having the strong $\{100\}\langle 011\rangle$ components as preferred orientations.

織の影響は認められなかつたが，強度と集合組織の関係 についてはさらに広範囲の条件下で調査する 必要があ る.

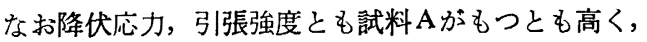
次いで試料 B，Cの順に低くなつているが，これは主と して結晶粒度によるものと考えられる。

\section{2 延性におよぼす集合組織の影響}

Fig. 6 に伸びと幅絞りの結果を示す. 伸びと幅絞りに ついては集合組織の影響は顕著で，集合組織のランダム な試料Aでは面内異方性は認められないが，これに対し て強い $\{100\}\langle 011\rangle$ 組織を有する試料 B，Cで注圧延方
向から $45^{\circ}$ に近い方向に引張つた場合に最大值が得らォ

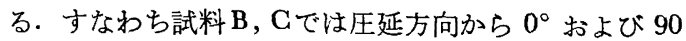
の方向（集合組織の方位が〈011〉方向）に近いほど作 び，幅絞りは小さく，圧延方向から $45^{\circ}$ の方向（<001 方向）に近くなると伸び，幅絞りは大きくなる.

これは単結晶について得られた結果と良く一致してい る21).この点で試料 B， Gは単結晶的挙動を示してい: といえるが，これは試料 B， Gにおける集合組織の分昔 が極めて小さいことによると考えられる.

試料 A, Bについて引張試験後の破断部形状を Photc 2 に示す. 集合組織のランダムな試料Aでは, 板幅方! 


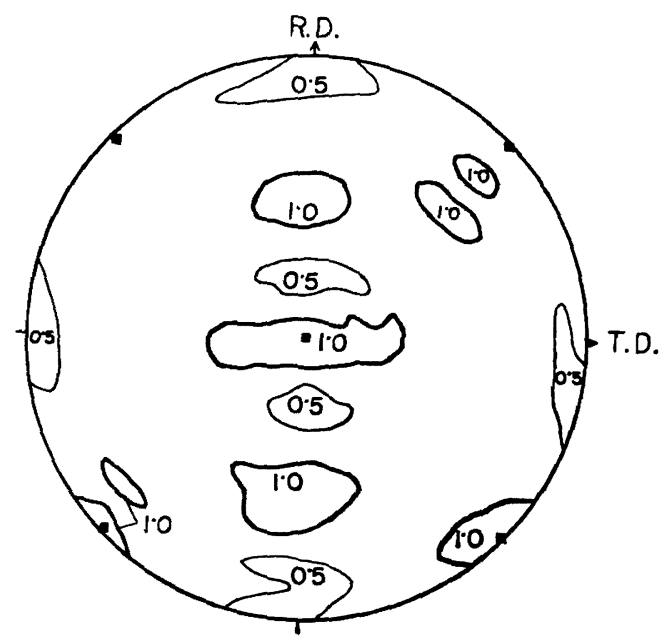

(a)

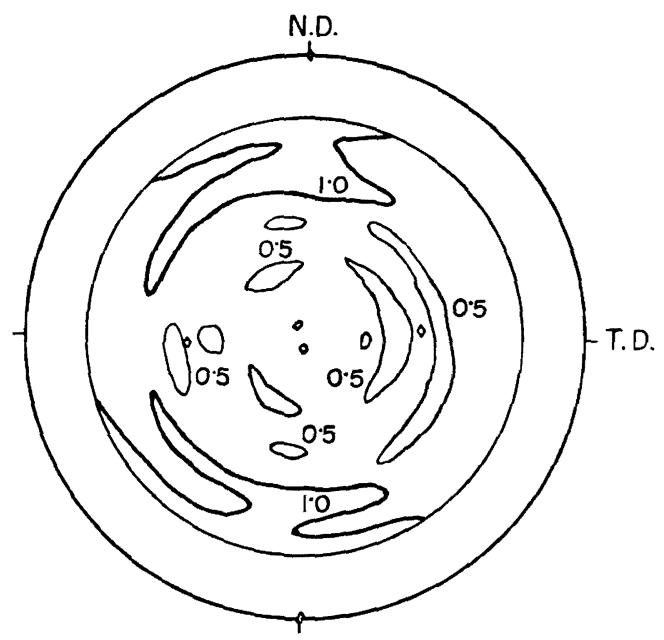

- $\bullet:\{100\}<011>$

(b)

の絞りがかなり大きく，破断面の形状は矩形で板厚方向 の厚みがある.これに対して強い集合組織を有する試料 Bでは幅絞りが極めて小さく，ほとえど板厚の減少で破 断に到つている. 圧延方向から $45^{\circ}$ の方向に近いと幅絞 りは增加するが，破断部形状はいずれの方向とも chiseledge 状を呈している.

以上の結果，本実験範囲では強度に対して集合組織の 影響は認められず, 単結晶におけるような結晶方位依存 性は得られなかつたが，延性については集合組織の影響 があり，強い $\{100\}\langle 011\rangle$ 組織を有する試料では些結晶 に似た挙動を示すことがわかつた。

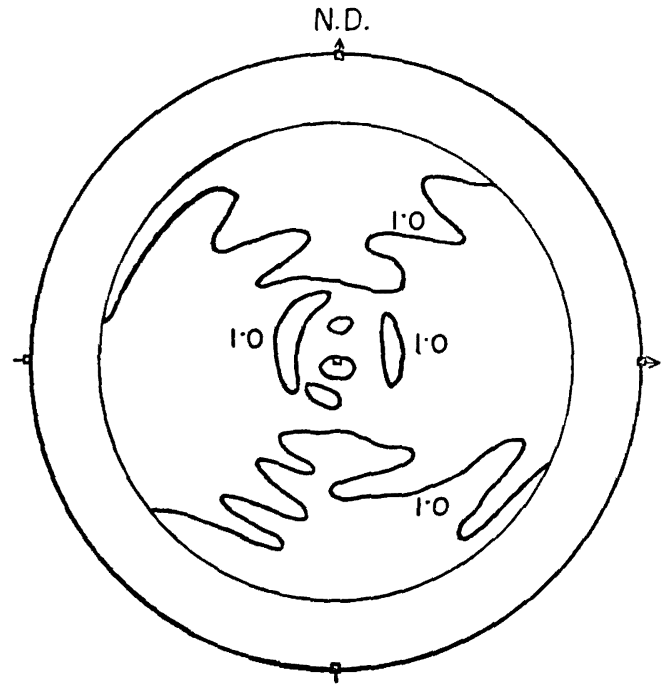

(c)

Fig. 2. 200 pole figures of sample A, having no preferred orientations.

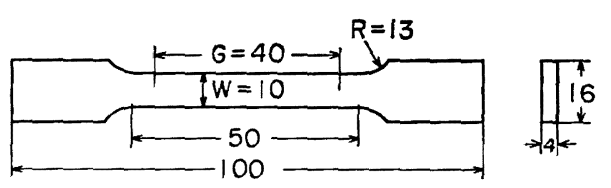

Fig. 3. Size of specimen for tensile test (unit : mm)

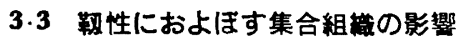

Fig. 7 は集合組織のランダムな試料Aについて, 衝撃 值と衝撃破面の遷移曲線を示したものである. 压延方向 から $0^{\circ}, 22 \cdot 5^{\circ}, 45^{\circ}$ 方向の断面ではいずれも遷移温度 はほぼ同一で試験方向による差は認められない. 圧延面 内では各方向とも衝撃値の遷移温度 ${ }_{\mathrm{V}} T_{\mathrm{E}}$ は約 $-50^{\circ} \sim$ $-60^{\circ} \mathrm{C}$ で，破面遷移温度 $\mathrm{v} T_{\mathrm{S}}$ は約 $-60^{\circ} \mathrm{C}$ である. 板厚方向 $\left(Z\right.$ 方向) では断面に比し僄移温度は高く ${ }_{\mathrm{v}} T_{\mathrm{E}}$ は約 $-5^{\circ} \mathrm{C}, \mathrm{v} T_{\mathrm{S}}$ は約 $-15^{\circ} \mathrm{C}$ となつており, また遷 移曲線は他の方向に比してゆつくり变化するという特徵 がある. shelf energy ( $\left.E_{\mathrm{S}}\right)$ は $45^{\circ}$ 方向がもつとも高 く, 次いで $22 \cdot 5^{\circ}, 0^{\circ}$ 方向の順に低くなり，Z方向は もつとも低い。

以上の結果から集合組織のランダムな試料Aでは, 遷 移温度の面内異方性はないことがわかる，Z方向の僄移 温度が断面方向に比し高いことについては, 介在物形状 や試験片製作方法（電子ビーム溶接）の影響が考えられ る.しかし光学顕微鏡観察の結果では, 介在物はほとん 上認められなかつた. さらにレプリカ法による電子顕微 

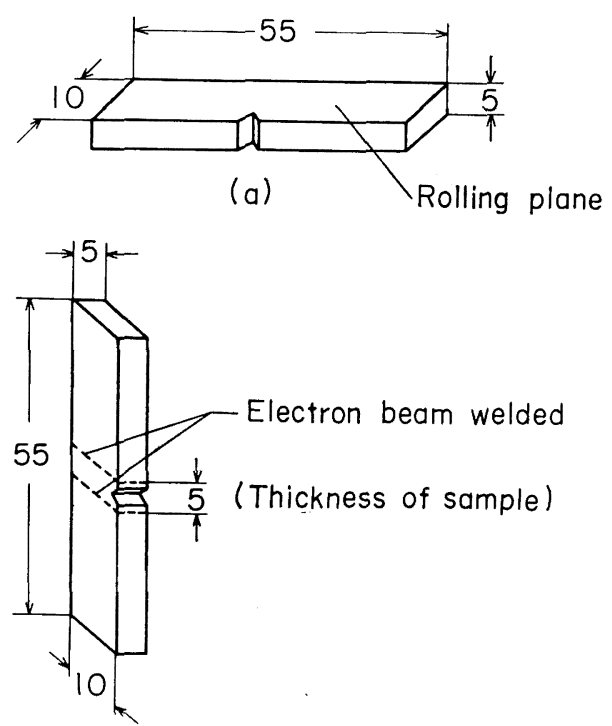

(b)

Fig. 4. Size of specimen for Charpy impact test (unit : mm).

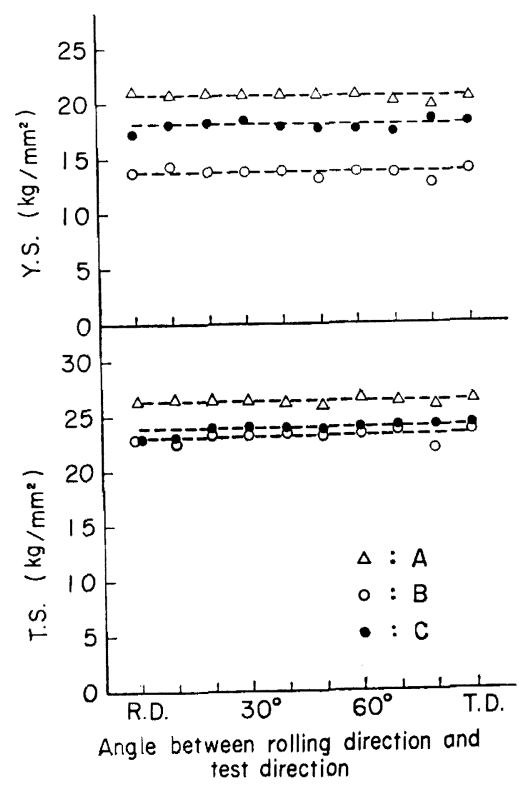

Fig. 5. Effects of texture on yield stress and tensile strength.

鏡観察を行なつたところ, Photo. 3 に示すように $0.1 \mu$ 以下の板出物はみられるが形状や分布に異方性は認めら れず， $Z$ 方向の異方性に影響するとは考光られない.な お析出物を同定したところ，大部分は $\mathrm{Fe}_{3} \mathrm{C}$ または $\mathrm{FeS}$

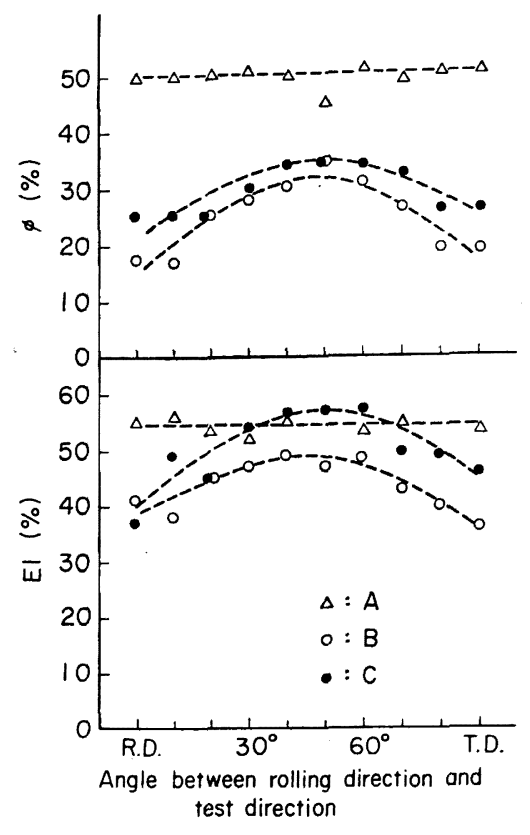

Fig. 6. Effects of texture on elongation and reduction in width.
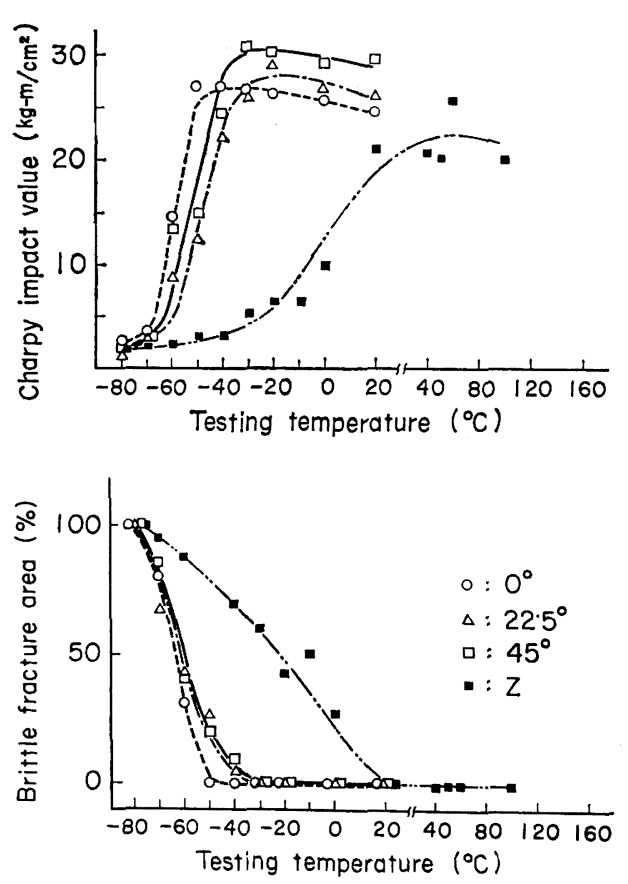

Fig. 7. Charpy impact transition curve (sample A)

であつた。また電子ビーム溶接の影響についても，歪は 試験片製作後焼鈍により除去しており，絬晶精も切欠 
A
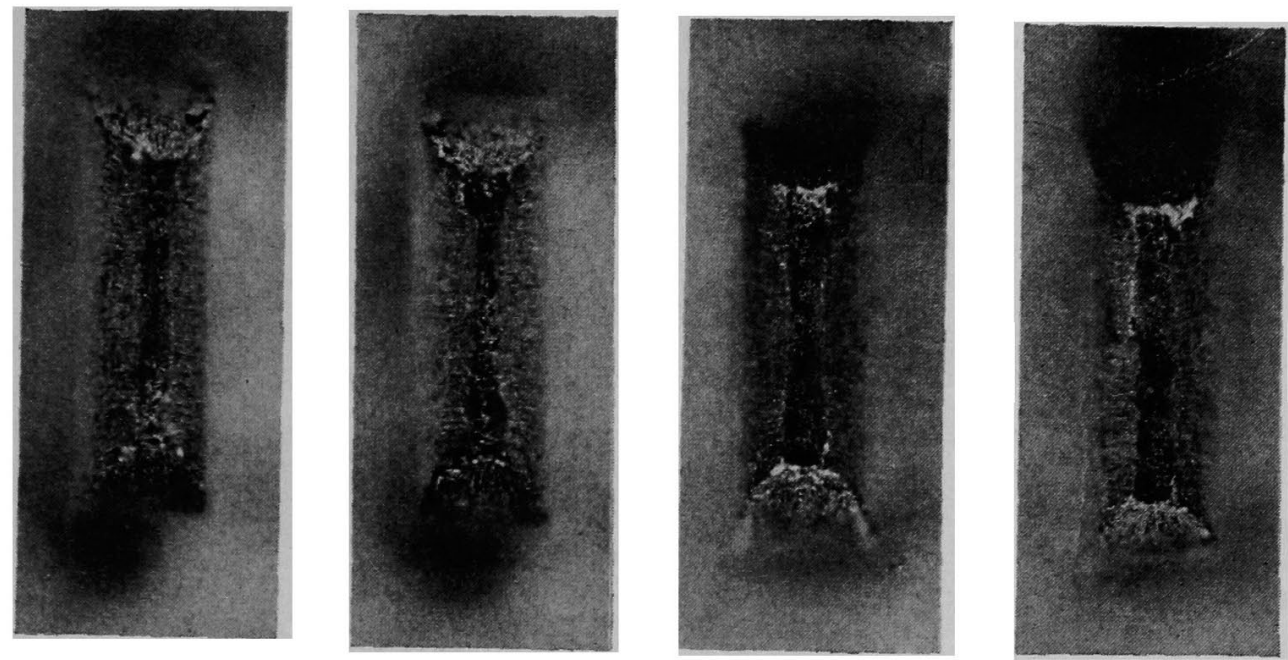

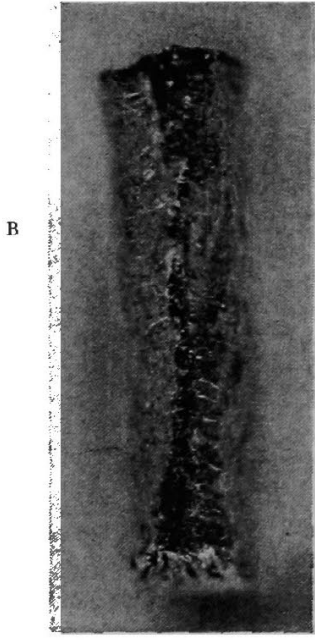

$0^{\circ}$

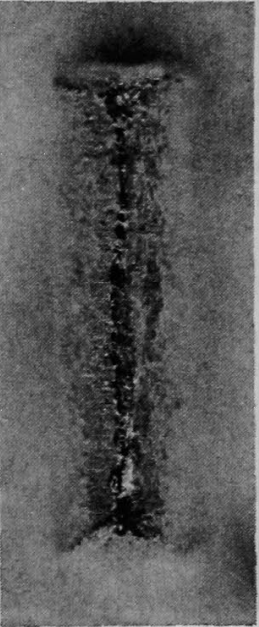

$30^{\circ}$

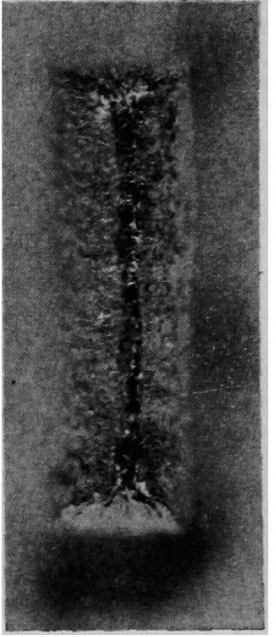

$60^{\circ}$

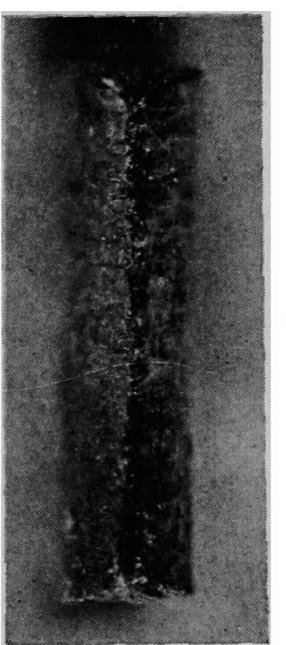

$90^{\circ}$

Photo. 2. Fractured appearances after tensile test (at R.T.)

部を含导約 $3 \mathrm{~mm}$ の範囲では変化は認的られず， $Z$ 方向 の遷移温度が高い原因について泣さらに検討を要する。 次:強い $\{100\}\langle 011\rangle$ 集合組織を有する試料 B の結果 をFig. 8 に示す. この試料では生延面内で差がみられ， 衝撃值の遷移温度 $\mathrm{v} T_{\mathrm{E}}$ は压延方向加 $0^{\circ}, 22 \cdot 5^{\circ}, 45^{\circ}$ 方向の順心高くなつて扔り，それぞれ $-45^{\circ} \mathrm{C},-30^{\circ} \mathrm{C}$, - $10^{\circ} \mathrm{C}$ である. 破面遷移温度 $\mathrm{v} T \mathrm{~S}$ もこれに対応してお り， $0^{\circ}, 22 \cdot 5^{\circ}, 45^{\circ}$ 方向でそれぞれ $-50^{\circ} \mathrm{C},-40^{\circ} \mathrm{C}$, $-20^{\circ} \mathrm{C}$ となつている. 板厚方向（ $Z$ 方向）の遷移温度 はこれらに比しずつと高く $\mathrm{v} T_{\mathrm{E}}, \mathrm{v} T_{\mathrm{S}}$ と約 $+120^{\circ} \mathrm{C}$ であり，また，遷移は急激に起こるという特徽がある。 shelf energy ${ }_{\mathrm{v}} E_{\mathrm{S}}$ は压延面内では各方问上も差がみら机
ず，Z方向のみ他の方向より低くなつている.

次に同じく強い集合組織を有する試料Cについて得ら れた結果を Fig. 9 亿示す。結果は試料 B とほぼ同し傾 向を示し， $T_{\mathrm{E}}$ は压延方向から $0^{\circ}, 22 \cdot 5^{\circ}, 45^{\circ}$ の方 向，Z方向の順に高くなり，それぞれ $-35^{\circ} \mathrm{C},-20^{\circ} \mathrm{C}$, $-10^{\circ} \mathrm{C},+90^{\circ} \mathrm{C}$ である. 破面の遷移温度 $\mathrm{v} T_{\mathrm{S}}$ は $0^{\circ}$, $22 \cdot 5^{\circ}, 45^{\circ}, Z$ 方向でそれデれ $-45^{\circ} \mathrm{C},-30^{\circ} \mathrm{C},-20$

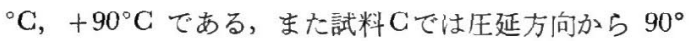
の方向についても試験を行ない，その結果 $0^{\circ}$ 方向とほ ぼ同一の遷移曲線を示すことを傕認した。

破面遷移温度 ${ }^{2} T_{\mathrm{S}}$ と試験方向の関係を Fig. 10 に示 しておくが, 以上の結果強い $\{100\}\langle 011\rangle$ 集合縕織を有 


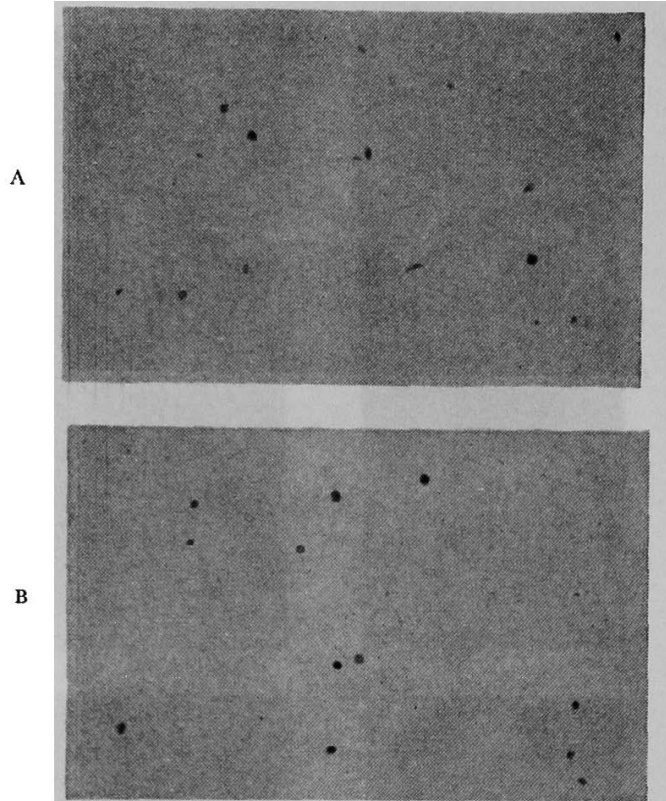

(a)

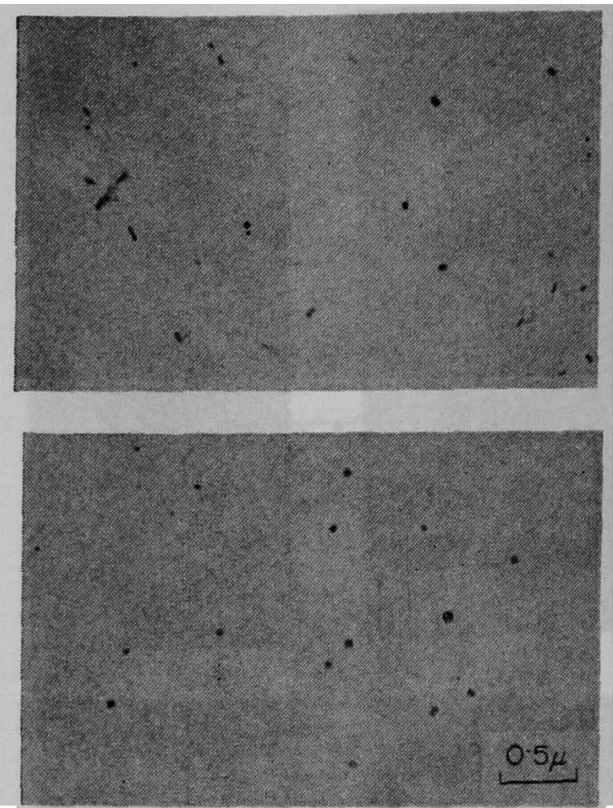

(b)

Photo. 3. Observations of precipitation in materials used : (a) normal section parallel to rolling plane (b) longitudinal cross section.
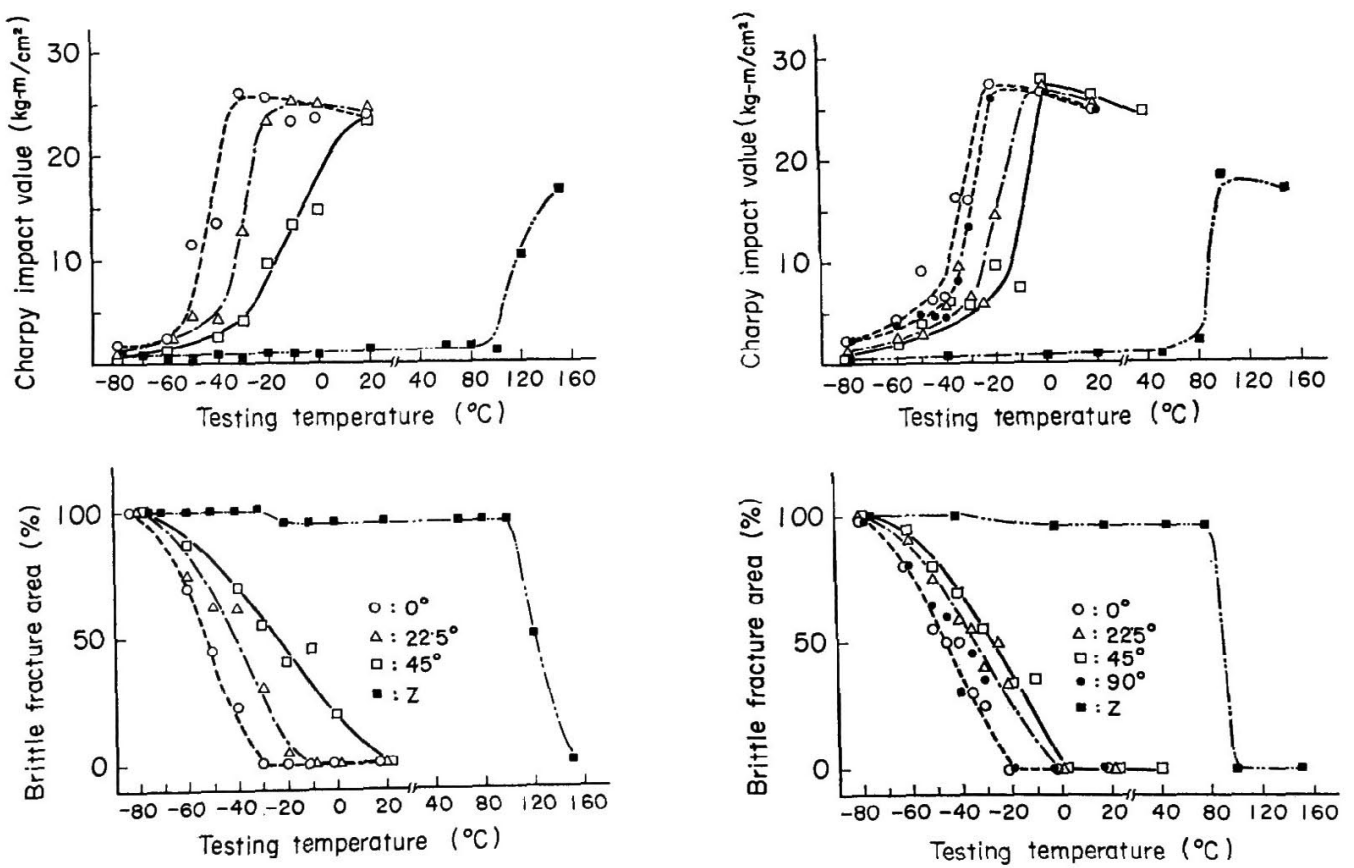

Fig. 8. Charpy impact transition curve (sample B) 


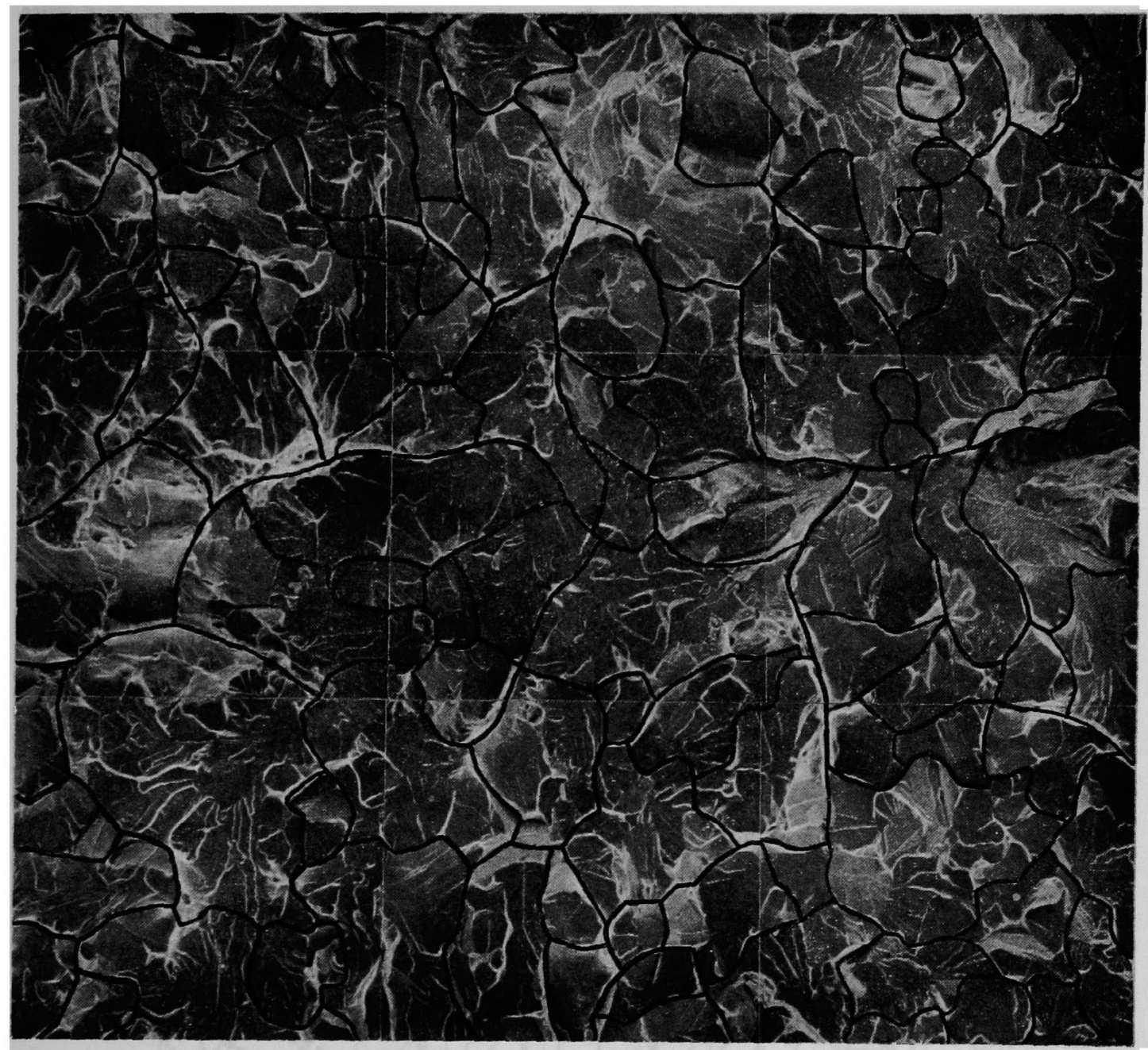

$100 \mu$

Photo. 4. Typical fracture surface of sample A after charpy impact test (in Z-direction)

する試料では遷移温度に異方性がみられ，特に $\{100\}$ 面 の多いZ方向および圧延方向から $45^{\circ}$ 方向の断面では㖶 移温度が高いことがわかつた。ただ $Z$ 方向については 集合組織のランダムな試料 $\mathrm{A}$ でも $\mathrm{v} T \mathrm{~S}$ で約 $45^{\circ} \mathrm{C}$ の差 があるが，その分を差引いても試料 B， G の Z 方向の $\mathrm{v} T_{\mathrm{S}}$ は $0^{\circ}$ 方向に比しそれぞれ $125^{\circ} \mathrm{C}, 90^{\circ} \mathrm{C}$ ほど高 くなつており集合組織の影響は強い.なお試料 $\mathrm{B}, \mathrm{C} の$ $Z$ 万向を除き遷移曲線の变化は純鉄としては全般にゆつ くりしているが，これはサブサイズ試験片を用いたこと にもよると考えられる.

\section{4. 検討}

\section{1 破面の穓察}

破面単位它測定するため，衝幋試験後の破面の走査型 電顕観察を行なつた．前述のように破面単位は微細黾裂 の生成伝播が生じている領域に相当し，その領域内では 破壞の生じている結晶面の方位がほぼ同-一の $\{100\}$ 䢃開 面をなしている.

Photo. 4 は集合組織のランダムな試料Aの破面の一例 であり，破面単位を図中の実線で示してある、この場合 破面単位証の境界が閉じて和り, その中の一点で発生 した微細酉裂は伝播して次の破面単位との境界で不連続 


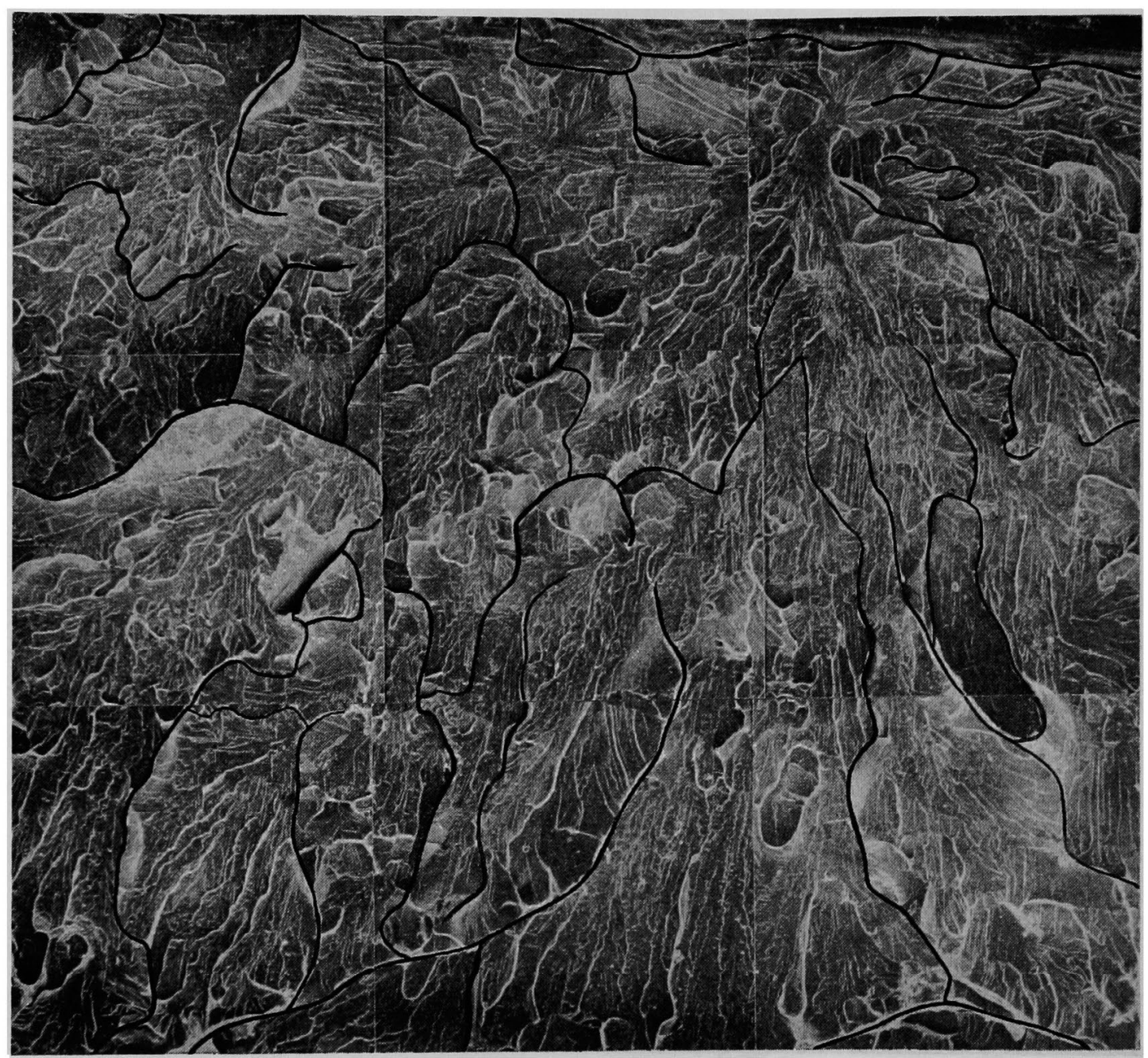

\section{$400 \mu$}

Photo. 5. Typical fracture surface of sample B after Charpy impact test (in Z-direction)

\section{になつている.}

これに対して強い集合組織を有与る試料 B では, Photo. 5 に示すように微細亀裂の発生源は一つでも伝播 の過程で別々の亀裂として生長する傾向にある. 図中の 実線は微細亀裂の境界を示したむので，この境界は試料 Aにおけるような破面単位の定義とは異なつているが， ここでは便宜上この境界を線分析により測定して得た平 均切片を破面単位と同様に取り扱うことにする.この点 については後でさらに論ずる.

以上の結果を Fig. 11 に模式的に示す. 四中で太線は 微細亀裂の境界（破面単低）を示し，細線は結晶粒界を 示したものである. 矢印の方向は微細重裂の伝播の方向
である．集合組織のランダムな材料では，破面単位を一 つの単位として微細舶裂の生成伝播は不連続的である. これに対して強い集合組織を有する材料では，一点から 発生した微細黾裂が伝播していく過程で別々の亀裂とし て生長与る傾向にある.このように集合組織の有鱓によ り破面単位の形成のしオに差異がみられるが，この点に ついては集合組織の強い場合の破面単位の定義や意味も 含めてさらに検討の要がある.

\section{$4 \cdot 2$ 䩒性と破面単位の関係}

従来䩳性におよぼす組織の影響としては，結晶粒度依 存性がよく知られ䩒性に関する PETCH の関係として多 くの蛜告がある(14)-16)，これに対して筆者の一人らは組 


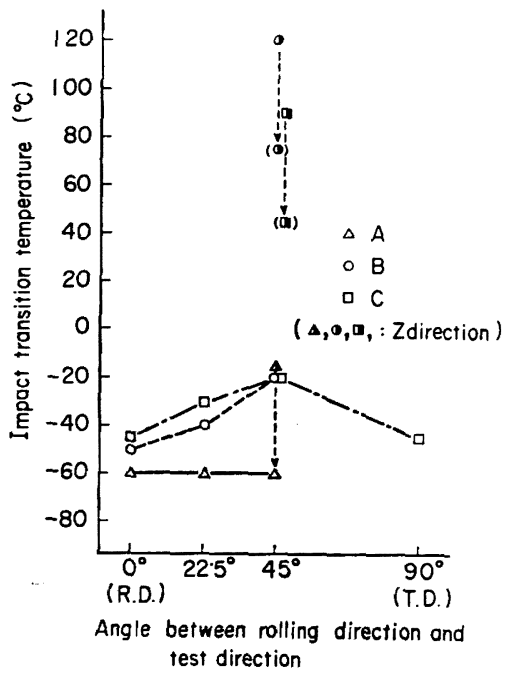

Fig. 10. Effects of texture on impact transition temperature (vTs). The plots of Z-direction in parenthesis are corrected using the difference between $\mathrm{Z}$-direction and other directions in sample $A$.

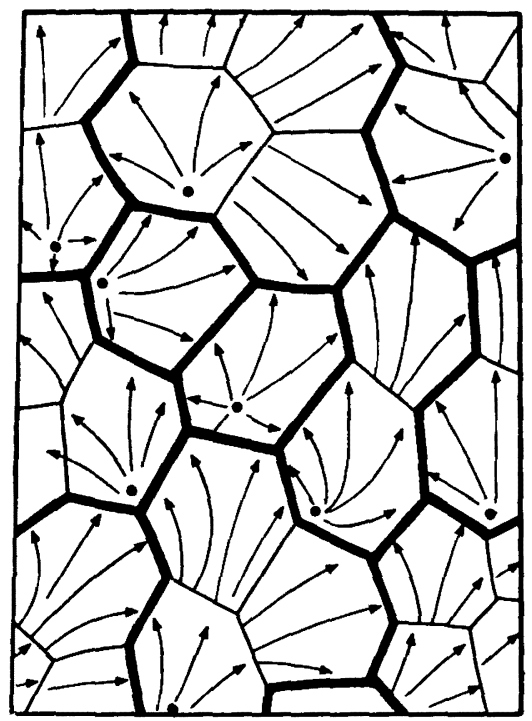

(a)
Table 3. Unit crack path observed in various sections of samples (unit : $\mu$, measured by linear analysis)

\begin{tabular}{c|c|c|c}
\hline & A & B & C \\
\hline (a) $Z$ & $77 \cdot 2$ & $397 \cdot 2$ & $322 \cdot 9$ \\
(b) $0^{\circ}$ & $75 \cdot 2$ & $166 \cdot 3$ & $135 \cdot 3$ \\
(c) $45^{\circ}$ & 76.6 & $196 \cdot 1$ & $165 \cdot 8$ \\
\hline
\end{tabular}

織の影響として破面単位が重要であることを指摘した ${ }^{17)}$ ～19).これは低温脆性破壊が $\{100\}$ 結晶面上に生じる䢃 開破壊であることから，ほほ同一の $\{100\}$ 䢃開面を共有 する破面単位の方が鞄性とより本質的な対応があるとい う考えに基づいたるのである。

ところで通常の熱処理範囲では, 結晶粒度 $l_{\alpha}$ と破面 単位 $l_{\mathrm{C}}$ とはほほ $l_{\mathrm{c}} \sim 2 l_{\alpha}$ という比例関係にあるため ${ }^{18)}$, 破面単位と靶性の関係について PETCH の関係との差異 を明らかにするのは困難であつた. しかし $\{100\}$ 集合組 織の強い材料を用いれば，結晶粒度と破面単位の比例関 係が变化し，破面単位の役割がより明らかになることが 期待された.

[破面単位の測定結果を Table 3 に示す。測定法結晶

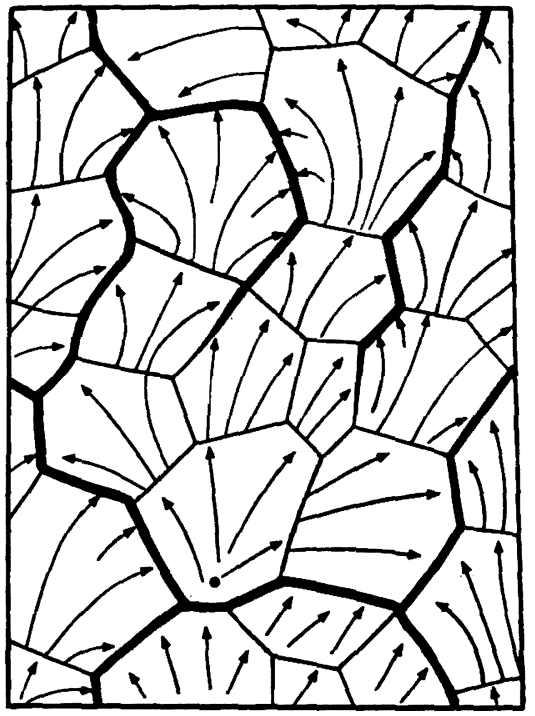

(b)

Fig. 11. Schematic illustration of cleavage fracture surface in : (a) sample having no preferred orientations (corresponding to Photo. 4):(b) sample having the strong $\{100\}\langle 011\rangle$ texture (corresponding to Photo. 5) Sharp and broad lines show the grain boundaries and the boundaries of microfractures, respectively. Arrows ind:cate the direction of microcrack propagation. 


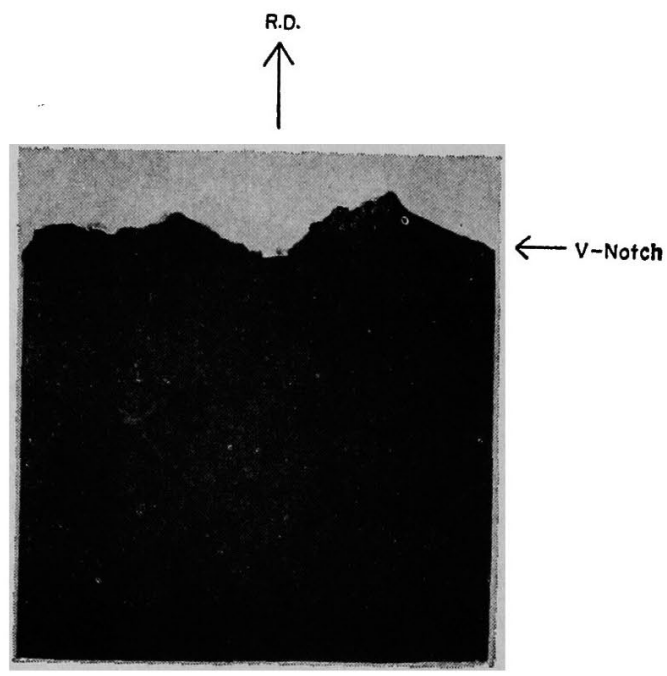

Photo. 6. Typical fractured appearance after Charpy impact test, testing in $0^{\circ}$ to rolling direction (sample B).

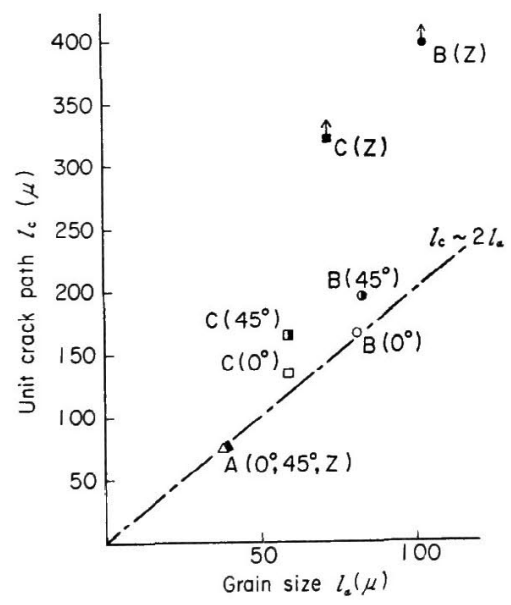

Fig. 12. Relation between grain $\operatorname{size}\left(l_{\alpha}\right)$ and unit crack path $\left(l_{\mathrm{c}}\right)$.

粒度の場合と同様線分析により行ない，試料 B， Cでは 前述のごとく微細重裂の境界を測定したものを破面単位 としている. Fig. 12 は結晶粒度と破面単位の関係を示 したものである. 集合組織のランダムな試料Aでは，い ずれの方ともほぼ $l_{\mathrm{C}} \sim 2 l_{\alpha}$ の関係にある. これに対し て強い集合組織を有する試料 $\mathrm{B}, \mathrm{C}$ で怯， $0^{\circ}$ 方向は $l_{\mathrm{C}} \sim$ $2 l_{\alpha}$ の関係に近いが， $45^{\circ}$ 方向の破面単位はこの関係よ り大きく，Z方向はさらに大きくなつている．たたし試 料 B, $\mathrm{C}$ の $0^{\circ}$ 方向については, 衝整破断面が Photo. 6 に示すように $\{100\}$ 方位にそつたような破断をしてい

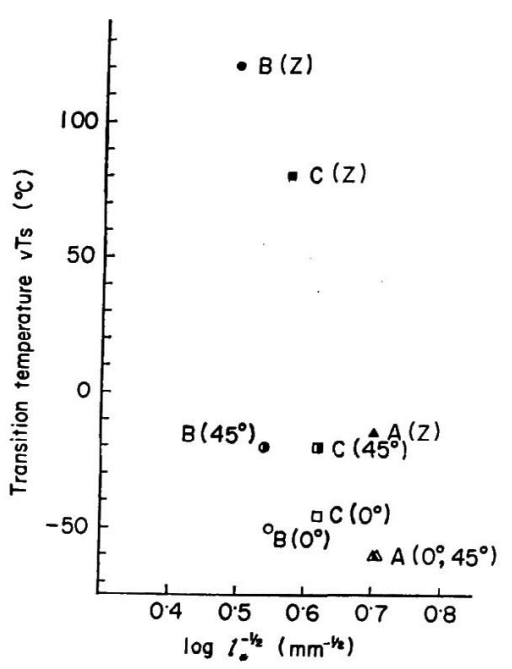

Fig. 13. Relation between impact transition temperature and grain size.

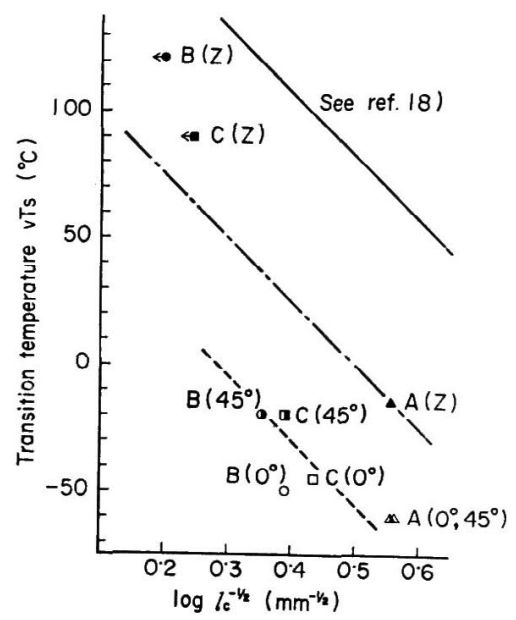

Fig. 14. Relation between impact transition temperature and unit crack path.

るため見かけ上破面単位が小さくなつており，実際には $45^{\circ}$ 方向の破面単位に近いとも考无られる.

いずれにしても強い集合組織を有する試料では, 破面 単位は $l_{\mathrm{C}} \sim 2 l_{\alpha}$ の関係より大きくなり，破断面に強い \{100\} 組織があるほどその傾向は大きいことがわかる. なお集合組織の強い材料では，前述のごとく集合組織の ランダムな材料とは破面単位の形成のし方に差異があり 実際の破面単位は今回の測定方法による結果よりさらに 大きい可能性もある.

次に靶性に対する組織の影響として，破面遷移温度 v $T_{\mathrm{S}}$ を絬晶粒度と破面単位で整理したものをそれぞれ 
Fig. 13，Fig. 14 に示す. 集合組織の強い試料 B， C で は遷移温度は $0^{\circ}, 45^{\circ}, Z$ 方向の順に高くなつている. ただし $Z$ 方向については集合組織のランダムな試料Aで も差があり，その原因として介在物，電子ビーム溶接の 影響を調べたが，調査の範囲では原因を明らかにするこ とはできなかつた.しかし試料 $\mathrm{A}$ における $Z$ 方向と断面 方向 $\left(0^{\circ}, 45^{\circ}\right)$ の $T_{\mathrm{S}}$ の差を用いて, 試料 $\mathrm{B}, \mathrm{C}$ の $Z$ 方向の ${ }_{\mathrm{v}} T_{\mathrm{S}}$ を補正することが妥当と仮定すれば， Fig. 10 に示したように試料 $\mathrm{B} ， \mathrm{C}$ の $Z$ 方向の $\mathrm{v} T_{\mathrm{S}}$ は やはり他方向に比し高いことがわかる．そこで強い集合 組織を有する試料 B，C における遷移温度 ${ }_{\mathrm{v}} T_{S}$ の異方 性を組織の影響としてみる必要がある．結晶粒度につい ては各試料間では差があるが，同一試料内では方向によ

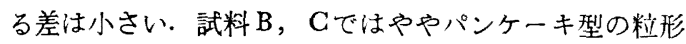
を示し $Z$ 方向の粒の平均切片は断面方向に比し若干大き くなつているが，Fig. 13 に示すようにその差は $\mathrm{v} T_{\mathrm{S}}$ の 異方性を説明するには不十分である. 寸なわち試料 B， $\mathrm{C}$ の $T_{\mathrm{S}}$ の巽方性を結晶粒度で整理すること，いい換 えると鞋性に関する PETCH の関係として把握すること は困難といえる。これに対して破面単位で整理してみる と，Fig. 14 に示すように破面単位が大きいほど遷移温 度 ${ } T_{\mathrm{S}}$ は高くなるという対応が認められる.なお Fig. 14 中の実線は前報18) のフェライトパーライト組織につ いて得られた関係を示している．本実験結果との差は主 として炭素含有量と試験片寸法の差によると考えられ る.

ところで試料 B， C の $0^{\circ}$ 方向と $45^{\circ}$ 方向について は， $T_{\mathrm{S}}$ と破面単位は対応しているようにみえるが， 前述のごとく $0^{\circ}$ 方向の破面単位を実際より小さく測定 している可能性があり必ずしも対応は明確ではない.む しろ $0^{\circ}$ 方向と $45^{\circ}$ 方向の $\mathrm{v} T \mathrm{~S}$ の差は, $0^{\circ}$ 方向での 衝撃破断面が Photo. 6 に示したように傾斜をもつてい るため，破断面に垂直な応力が小さくなつていることに もよると考えられる。

しかし試料 B，Cの $Z$ 方向については，破面単位は他 方向に比し著しく大きく $\mathrm{v} T_{\mathrm{S}}$ と対応している．また集 合組織の強い試料では破面単位はさらに大きい可能性も あり, Fig. 14 に示したように前報 ${ }^{18)}$ のェライトーパ 一ライト組織で得られた傾向が本実験の場合にも成立す るとすれば，その可能性は大きい。これらの点からみて 僄移温度は結晶粒度より破面単位で整理する方がより妥 当と考えられる.

以上集合組織の強い材料では，破面単位 $l_{c}$ は結晶粒 度 $l_{\alpha}$ に比し従来の関係 $l_{\mathrm{C}} \sim 2 l_{\alpha}$ より大きいことがわか り，遷移温度は結晶粒度より被面単位で整理する方がよ
り妥当と考えられた。しかし靶性におよほす組織の影響 としての破面単位の役割を十分明らかにしたとはいい難 く，鞄性に関する Р $\mathrm{ETCH}$ の関係との差異を明確にする ためには，同一素材より得た種々の結晶粒度の試料を用 いるなどさらに精密な実験が必要であろう.

\section{5. 結言}

純鉄を用いて，圧延面に平行な強い $\{100\}\langle 011\rangle$ 集合 組織を有する材料と集合組織のランダムな材料について 鞄性, 延性, 強度におよほす集合組織の影響を調査し, 次の結果を得た。

（1）衝撃性質には集合組織の影響があり，破壊の方 向に強い $\{100\}$ 組織があると遷移温度は高くなる.

（2）集合組織の強い材料では, 破面単位 $l_{\mathrm{C}}$ は結晶 粒度 $l_{\alpha}$ に比し従来の関係 $l_{\mathrm{C}} \sim 2 l_{\alpha}$ より大きくなる. 遷 移温度は結晶粒度より破面単位で整理する方が妥当と考 えられる、なお集合組織の有無により破面単位の形成の し方に差異があり, 詳細な検討は今後の問題である.

（3）伸び，幅絞りには集合組織の影響があり，集合 組織の〈011〉方向に比し〈001〉方向での伸び, 幅絞り が大きい.

（4）本実験範囲では強度には集合組織の影響は認め られない.

おわりに, 本研究の発表を許可された中央技術研究所 所長池島俊雄博士，ならびに多くの有益なご助言をいた だいた邦武立郎博士に深甚なる感謝の意を表する.

\section{交献}

l) R.S. Burns and R. H. Heyer: Sheet Metal Ind., 35 (1958), p. 261

2) R. L. Whiteley and D. E. Wise: Flat Rolled Products I , 16 (1962), p. 47

3 ) J. A. Ellias, R. H. Heyer and J. M. Smith: Trans. AIME, 224 (1962), p. 679

4 ) $T$. Okamoto, $T$. Shiraiwa and $M$. Fukuda: Colloquium of International Deep Drawing Research Group, Institute of Sheet Metal Engineering, London, 1964

5 ) 久保田, 小指, 清水：日本金属学会誌, 32 (1968), p. 1074

6 ）小指, 稲垣, 栗原, 三瓶, 大北 : 鉄と鋼，59 (1973), p. A 49

7) B. Edmondson: Proc. Roy. Soc., A264(1961), p. 176

8 ) F. Terasaki: Acta Met., 15 (1967), p. 1057

9) F. Terasaki: Métaux, Corrosion, Industrie, 497 (1967), p. 11

10) R. Priestner and $N$. Louat: Acta Met., 11 (1963), p. 195

11) T. H. Webster: Acta Met., 18 (1970), p. 683 
12) R. SChofield: JISI (1973), p. 374

13) 三好，寺崎，金子：鉄と鋼（投稿予定）

14) A. N. Stroh: Adv. Phys., 6(1957), p. 48

15) N. J. Ретсн: Phil. Mag., 3 (1958), p. 1089

16) A. H. Cottrell: Trans. AlME, 212 (1958), p. 192

17）寺崎, 大谷 : 鉄と鋼, 58 (1972), p. 293

18）寺崎, 大谷：鉄と鋼，58 (1972), p. 1067
19) $F$. Terasaki and $H$. Ohtani: Trans. ISIJ, 1 (1972), p. 45

20) $H$. Ohtani, $F$. Terasaki and $T$. Kunitake: Trans. ISIJ, 12 (1972), p. 119

21) T. TAkeuchI: Trans. JIM, 9 (1968), p. 871

22) T. H. Webster, I. L. Dillamore and $R$. $E$. Smallman: Metal Sci. J., 5 (1971), p. 74 